\title{
THE EFFECT OF PRODUCT QUALITY, SERVICE QUALITY, REFERENCE GROUPS FOR REPURCHASE INTENTION IN A KOPI GAPTEK SURABAYA
}

\author{
Mochammad Chavi Abdullah ${ }^{1}$, Joko Suyono ${ }^{2}$ \\ chavi.aidit@gmail.com ${ }^{1}$, joko.suyono@narotama.ac.id ${ }^{2}$ \\ Departement of Management, Faculty of Economics and Business, Narotama University \\ Jl. Arief Rachman Hakim 51, Sukolilo, Surabaya
}

\begin{abstract}
The intention to repurchase is the intention to repurchase a product twice or better for the same or different products. Therefore this study aims to analyze whether product quality, service quality, and reference groups can influence consumers' repurchase intention to buy gaptek coffee shop products located in jl. dinoyo. This research is quantitative research with a sample of 160 respondents. Furthermore, the data were analyzed using multiple linear regression analysis techniques and classical assumption tests. The results showed that three hypotheses showed 1 was not significant (product quality) and the other showed significance.
\end{abstract}

Keywords: Product Quality, service quality, reference group, Consumer Repurchase intention

\section{INTRODUCTION}

Today entertainment is sought after by many people, both among workers, students or students with the aim of eliminating fatigue, boredom and boredom caused by daily routines. In dealing with this, people can look for entertainment such as watching a movie, karaoke or going to a café to drink coffee with friends or relatives.

And in recent years there have been many coffee shop businesses that offer a variety of facilities and services to tax consumers. This is marked by the emergence of many coffee shops and now coffee in stores is a habit for some Indonesians, especially the number of films that raise the theme of coffee. drinking coffee is increasingly mushrooming in Indonesia.

In Surabaya, there are many coffee shops that stand up with various advantages, some rely on cafe designs in such a way that customers are comfortable in the cafe, some rely on or prioritize products, some even prioritize services such as the Kopi Gaptek shop located in Dinoyo Surabaya, to face their intense competition prioritizes the coffee products they sell and the services provided to visitors.

\section{THE ORETICAL FRAMEWORK}

\section{Product quality}

Product quality is the ability of an item to deliver the right results or performance that exceeds what the customer wants (Kotler and Keller 2012)

\section{Service quality}

Service quality is any action or activity that can be offered by a party to another party, which is basically intangible and does not result in any ownership. (Kotler 2002)

\section{Reference group} heyman 2009)

Reference groups are defined as people or groups of people who influence meaningfully (Herbet

\section{Intention to repurchase}

Repurchase intention is defined as an individual's judgment about buying another service or product that is bought in the same place by considering the current site and the enabling circumstances. (Hellier 2003) 


\section{RESEARCH METHODS}

\section{Types of research}

This type of research is causal research (looking for a cause and effect by using a hypothesis), where the object of this research is a case study conducted on people who have already bought gaptek coffee shop products in Surabaya. This study will use a quantitative approach, according to Sugiyono (2016) quantitative method is a scientific approach that views a reality that can be classified, concrete, observable, and measurable, the relationship of variables is causal where the research data is in the form of numbers and the analysis uses statistics. The independent variables in this study are product quality, service quality and the reference group of the dependent variable for consumer repurchase intention. The purpose of this study is more towards the results of generalizations, explaining phenomena in a more measurable manner and various evidences to be found. Data collection to obtain results of discussion, analysis and conclusions that can be accounted for.

Time and Place of Research

This research was conducted at the gaptek coffee shop. The study was conducted from March 2019 August 2019.

\section{Research Framework}

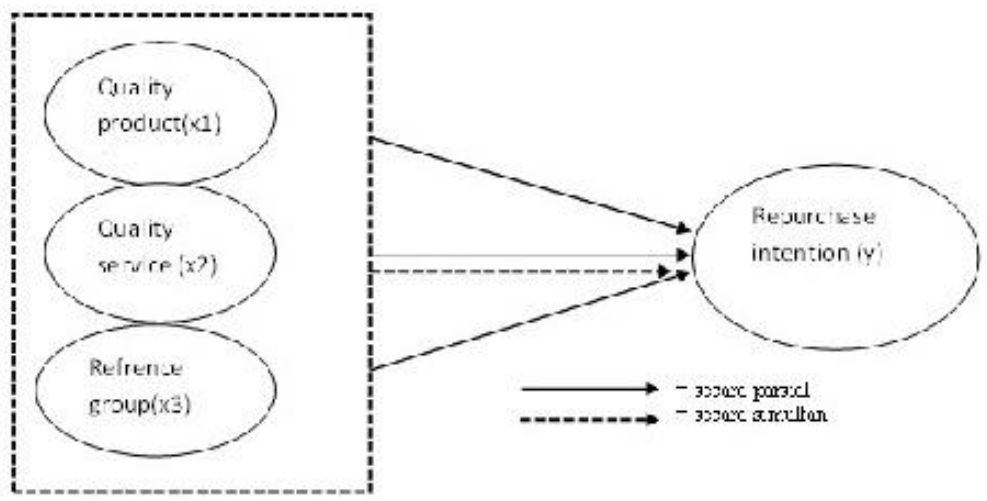

\section{Population and Samples}

The population in this study is Non-consumers or people who have never purchased the UKM Wedoro product in Sidoarjo. The sample is part of the number and characteristics possessed by the population (Sugiyono, 2012). The sampling technique used is a non-probability sampling technique precisely purposive sampling. According to (Sugiyono, 2013) purposive sampling is a technique of taking until the source of the data with certain considerations. This particular consideration, for example the person who is considered to know the best about what we expect. The number of samples taken is 160 people

\section{Method of collecting data}

The data sources used in this study use primary data and secondary data. Primary data is data obtained directly from the object of research. And secondary data, researchers get from data that has been processed by third parties, through books, libraries, libraries, and sources from the internet.

\section{Definition of Operations Variable Research}

\section{X1: Product quality}

Product quality is a product that meets specifications - specifications that can satisfy consumers of the smart coffee shop

X2: service quality

service quality is the quality of service is all forms of activities carried out by the company to meet consumer expectations. Service in this case is defined as the service or service delivered by the service owner in the form of convenience, speed, relationship, ability and hospitality that is addressed through attitudes and characteristics in providing services for customer satisfaction in this case the satisfaction of consumers of gaptek coffee shops 
X3: reference group

The reference group is an individual or group that can significantly influence a person in this case affecting consumers to repurchase to the custodian coffee shop

Y: intention to repurchas

Repurchase intention is the intention to repeat the product twice or better for the same product

\section{Data analysis method}

\section{Reliability and Test Validity Test}

Test Reliability is actually a tool to measure a questionnaire which is an indicator of a variable or construct. A questionnaire is said to be reliable or reliable if someone's answer to a question is consistent or stable over time. Questionnaire items are said to be reliable (feasible) if cronbach's alpha> 0.06 and are said to be unreliable if cronbach's alpha <0.06. (Ghozali 2012). Test Validity is used to measure the validity of a questionnaire. It is valid if the questionnaire is able to reveal something that will be measured by the questionnaire. Testing this validity using Pearson Correlation is by calculating the correlation between the values obtained from the questions. A question is said to be valid if the level of significance is below 0.05 (Ghozali 2012)

\section{Multiple Regression Analysis Model}

The analysis used in this study is multiple linear regression analysis. Multiple linear regression analysis was used to analyze the influence of independent variables (Product Quality, Word Of Mouth, and Location) on the dependent variable, namely consumer buying interest.

The mathematical formula of multiple linear regression used in this study is:

$\begin{aligned} & \mathrm{Y}=\mathrm{a}+\mathrm{b} 1 \mathrm{X} 1+\mathrm{b} 2 \mathrm{X} 2+\mathrm{b} 3 \mathrm{X} 3+\mathrm{b} 4 \mathrm{X} 4+\mathrm{e} \\ & \mathrm{Y}=\text { Repuchase intention } \\ & \mathrm{a}=\text { Konstanta } \\ & \mathrm{b} 1, \mathrm{~b} 2, \mathrm{~b} 3=\text { Koefisien regresi } \\ & \mathrm{x} 1=\text { quality product } \\ & \mathrm{x} 2=\text { quality service } \\ & \mathrm{x} 3=\text { reference group } \\ & e=\text { error disturbances }\end{aligned}$

\section{RESULTS AND DISCUSSION}

\section{Results}

\section{Reliability and validity}

This research data has cronbach's alpha 0.924 and is above 0.60 , then this research data can be declared reliable and reliable while testing the validity of product quality variables (X1), service quality (X2), and reference group (X3), and purchase intention Reset (Y) used in this study has a correlation coefficient or r-count which is greater than rtable $=0.1305$ (rtable value for $\mathrm{n}=160$ ). So that all these indicators are valid.

Results of Multiple Linear Regression.

\begin{tabular}{|l|l|l|l|l|l|}
\hline \multirow{2}{*}{ Model } & \multicolumn{2}{|c|}{ Coefficient $^{2}$} & \multirow{2}{*}{ Snstandardized Coefficient } \\
\cline { 2 - 6 } & \multicolumn{2}{|c|}{ B } & $\begin{array}{c}\text { Standardtized } \\
\text { Coefficient }\end{array}$ & \multirow{2}{*}{ t } & Beta \\
\hline (Constant) &, 086 &, 253 & &, 341 &, 734 \\
\hline X1 &, 019 &, 086 &, 016 &, 222 &, 824 \\
\hline X2 &, 487 &, 076 &, 475 & 6,422 &, 000 \\
\hline
\end{tabular}


a. Dependent Variable: $Y$

Regression equation models that can be written from these results in the form of standard regression equations are as follows

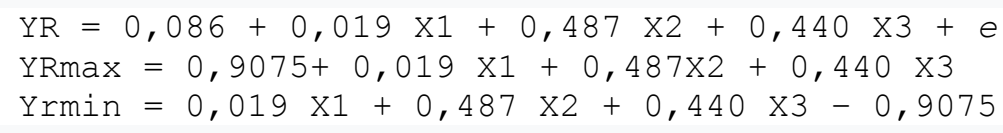

\section{Value of $\mathbf{R}$}

$\mathrm{R}$ value of 0.797 shows that the correlation / relationship between purchase intention with 4 independent variables (product quality, service quality, and reference group) is strong because the value of $\mathrm{R}$ is 0.797 above 0.5

Standard Error of Estimate (SEE)

The value of SEE is 0.459 , which means the error rate of the regression model is quite large but still below 1. The smaller the value of the standard error of estimate (SEE), the regression model is more appropriate in predicting repurchase intention.

\section{Constant}

Constant value $\mathrm{Y}$ is 0.086 , which means buying interest from gaptek coffee shops below 1 , unit if it is assumed that product quality, service quality, and reference group is 1 means if the value of independent variable 1 then the dependent or dependent variable will be 0.086 .

\section{Value of product quality coefficient (X1)}

The product quality coefficient $\mathrm{X} 1$ is 0.019 , if the product from the coffee shop is difficult to improve product quality (X1) it will increase the repurchase intention (Y) by 0.019 units. Assuming the value of service quality $(\mathrm{X} 2)$, the reference group (X3) is zero.

\section{Service Quality Coefficient Value (X2)}

The coefficient of service quality X2 is 0.487 , if the product from the Green Shop Distro improves service quality (X2) it will increase the repurchase intention (Y) by 0.487 units. Assuming the value of product quality (X1), the reference group (X3) is zero.

\section{Reference group coefficient value (X3)}

The product quality coefficient X1 is 0.440 , if the product from the Green Shop Distro improves product quality (X1) it will increase the repurchase intention (Y) by 0.440 units. Assuming the value of product quality (X1) service quality $(\mathrm{X} 2)$ is zero.

Classic assumption tes

\section{Normality Test Calculation Results}




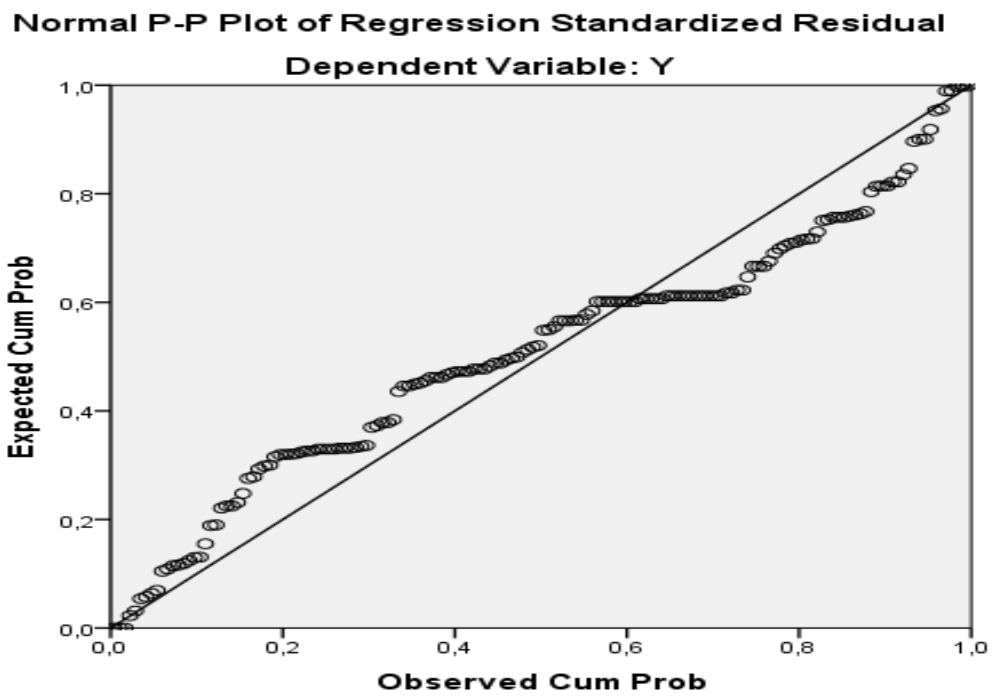

it can be seen that the standardized graph of normal probability plot of regression shows a normal graph pattern. This can be seen from the points that spread around the diagonal line and the diagonal line from the lower left to the top right. Then it can be concluded that the regression model is feasible because it meets the assumptions of normality.

\section{2) Multicollinearity Test}

The multi collinearity test in this study can be seen as follows: Multicollinearity Test

\begin{tabular}{|c|l|l|}
\hline Coefficient $^{2}$ & \multicolumn{2}{l|}{} \\
\hline Model & \multicolumn{2}{|l|}{ Colleniarity Statistics } \\
\cline { 2 - 3 } & Tolerance & VIF \\
\hline X1 &, 462 & 2,170 \\
\hline X2 &, 462 & 2,345 \\
\hline X3 &, 599 & 1,670 \\
\hline
\end{tabular}

it can be seen that the regression model does not experience multicollinearity disorders. This can be seen in the tolerance value of each independent variable greater than 0.1. The VIF calculation results also show that the VIF value of each independent variable is less than 10. So it can be concluded that there is no multicollinearity between the independent variables in the regression model.

\section{3) Heteroscedasticity Test}

Graphs of testing Heteroskedactivity can be explained in the following picture 


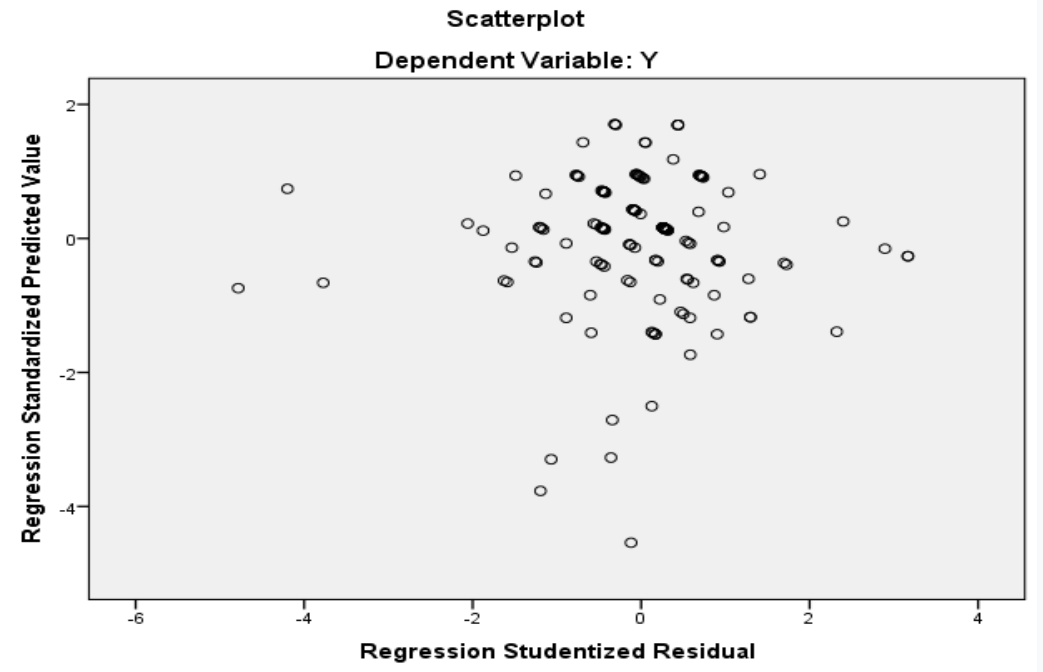

Based on the graph above, it can be seen that the distribution of data is irregular and does not form a specific pattern, and spreads above and below the number 0 on the $\mathrm{Y}$ axis, so it can be concluded that in this regression model there is no problem of heteroscedasticity

Hypothesis testing

\section{F-test}

The F test is used to determine all effects of all independent variables on the dependent variable. This test is done by comparing the Fcount value with Ftable value at $\alpha=0.05$.

\begin{tabular}{|cl|c|c|c|c|c|}
\hline Model & $\begin{array}{c}\text { Sum of } \\
\text { Square }\end{array}$ & df & $\begin{array}{c}\text { Mean } \\
\text { Square }\end{array}$ & F & Sig \\
\hline \multirow{2}{*}{1} & Regression & 57,551 & 3 & 19,184 & 90,859 &, $000^{\mathrm{b}}$ \\
\cline { 2 - 7 } & Residual & 32,937 & 156 &, 211 & & \\
\cline { 2 - 7 } & Total & 90,489 & 159 & & & \\
\hline
\end{tabular}

\section{CONCLUSIONS AND RECOMMENDATIONS}

\section{Conclusion}

Based on the discussion of the results of the research in chapter 4, it can be concluded as follows:

1) Product quality (X1) has no significant effect on repurchase intention (Y). Where the value of the value of $t$ count $=, 222>$ of ttable 1,975 with a significance of $0,000<0,05$ means less significant means that the quality of the product does not affect the intention to repurchase consumers.

2) Service quality (X2) influences the significance of repurchase intention (Y). Where the value of tcount = $6.422>$ from ttable 1.975 with a significance of $0.000<0.05$ means significant .. This is perceived service quality by customers who agree that the service quality of the gaptek coffee shop has the effect of repurchase intention.

3) The reference group (X3) has a partial effect on Purchase Intention (Y). Where the value of tcount $=6.429>$ from ttable 1.975 with a significance of $0.000<0.05$ means significant. . This is perceived by the reference group of customers who agree that the gaptek coffee shop products have the effect of repurchase intention.

4) Product quality variable (X1) does not significantly influence repurchase intention while service quality (X2) and reference group (X3) have a simultaneous effect on Purchase Intention (Y) with a significant value smaller than 0.05 , which is 0,000 .

\section{Suggestion}

1. For Researchers For the next researcher, it is expected to conduct a re-research because the quality of the product does not significantly influence the intention to repurchase

2. For Companies It is expected to improve the quality of their products to be able to attract consumers to repurchase their 
6. REFERENCES

Adoyo, B., Ondoro, C. O., \& Aila, F. O. (2012). The Relationship between Customer Service Quality and Customer Loyalty among Retail Pharmacies in Western Kenya, 2(3), 11-21.

Alex, D., \& Thomas, S. (2015). Impact of Product Quality , Service Quality and Contextual Experience on Customer Perceived Value and Future Buying Intentions Impact of Product Quality, Service Quality and Contextual Experience on Customer Perceived Value and Future Buying Intentions, (August).

Arsyanti, N. M., Rahayu, S., \& Astuti, T. (2016). Analisis Pengaruh Kualitas Produk , Kualitas Layanan dan Keragaman Produk Terhadap Kepuasan Pelanggan Serta Dampaknya Terhadap Minat Beli Ulang ( Studi pada Toko Online Shopastelle, Semarang ), 5, 1-11.

Brata, B. H., Husani, S., \& Ali, H. (n.d.). The Influence of Quality Products , Price , Promotion , and Location to Product Purchase Decision on Nitchi At PT . Jaya Swarasa Agung in Central Jakarta, 433-445. https://doi.org/10.21276/sjbms

Ghozali, I. (2009) Aplikasi Analisis Multivariate dengan Program SPSS. 4th edn. Semarang: UNDIP.

Ghozali, I. (2005) Aplikasi Analisis Multivariate dengan Program SPSS. 3rd edn. Semarang: UNDIP.

Ghozali, I. (2006) Aplikasi Analisis Multivariate dengan Program SPSS. Semarang: UNDIP.

Hanaysha, J. (n.d.). The Influence of Product Quality and Service Quality on Brand Leadership : Empirical Evidence from Malaysia.

Kualitas, P., Dan, L., Harga, P., \& Harjati, L. (2015). MASKAPAI PENERBANGAN TIGER AIR MANDALA, 1 .

Kotler and Keller (2009) Manajemen Pemasaran. 13th edn. Jakarta: erlangga.

Kotler and Keller (2012) manajemen pemasaran. 12th edn. jakarta: erlangga.

Kotler, P. (2008) Manajemen Pemasaran. 12th edn. Jakarta: Indeks.

Kotler, Philip and Armstrong (2014) Prinsip-prinsip manajemen. 14th edn. jakarta: erlangga.

Massie, J. D. D., Ekonomi, F., \& Manajemen, J. (2017). PENGARUH KELOMPOK ACUAN DAN BRAND IMAGE TERHADAP MINAT BELI SMARTPHONE THE INFLUENCE OF REFERENCE GROUP AND BRAND IMAGE ON BUYING INTEREST OF, 5(3), 3714-3723.

Pembelian, K., Jambi, B., \& Kota, D. I. (2015). Abstrak, 17.

Prakoso, H. W., \& Kunci, K. (2015). PENGARUH KUALITAS PRODUK DAN KELOMPOK ACUAN TERHADAP KEPUTUSAN PEMBELIAN SEPEDA MOTOR SUZUKI SATRIA F150, 262-279.

Salfina, L. et al. (2018) 'Pengaruh Citra Merek, Kualitas Produk Dan Harga Terhadap Minat Beli Pakaian AnakAnak Studi Kasus Toko Rizky Dan Afdal Pariaman’, 1(1), pp. 83-100. doi: 10.30985/ji.v1i1.5.

Sugiyono (2013a) Metode Penelitian Kuantitatif Kualitatif dan R\&D. Bandung: Alfabeta.

Sugiyono (2013b) Metode Penelitian Manajemen. Bandung: Alfabeta.

Swastha, B. (2002) Manajemen Pemasaran. kedua. jakarta: Liberty.

Tjiptono, F. (2002) Manajemen Jasa. maret-tahu. Yogyakarta: ANDI.

Tjiptono, F. (2006) Manjemen Jasa. pertama. Yogyakarta: Andi.

Tjiptono, F. and Chandra, G. (2012) Pemasaran strategik. Yogyakarta: ANDI.

Massie, James D D, Fakultas Ekonomi, and Jurusan Manajemen. 2017. 